\title{
The 'New Economy' and the Old Problems: Prospects for Fast Growth in Postsocialist Countries
}

\author{
Grzegorz W. Kolodko*
}

\begin{abstract}
The 'new economy' provides a fresh opportunity to enhance growth. However, to turn such prospect into reality, the postsocialist countries - unlike developed market economies - need not only aptly utilise the potential of e-business, but first raise efficiency of the 'old economy', since these two 'economies' are destined for a lengthy coexistence.
\end{abstract}

\section{JEL Classification: $\mathrm{F} 43, \mathrm{O} 3$}

Key words: Computorisation, Globalisation, Internet, New economy, Post-socialist countries

\section{Globalisation in the Internet Age}

The fourth industrial revolution is under way, connected with the proliferation of information technology and the computerisation of nearly all spheres of human activity. Over the time-span of a single generation - between 1970 and 2000 - the cost of computing power dropped on an unprecedented scale: by a factor of nearly 50,000 . Thirty years ago, per-megahertz cost of processors stood at $\$ 7,600$; now it is a mere 15 cents. The scale of the simultaneous reduction in the cost of RAM (per megabyte) was in the order of 30,000 . In the case of data transmission, prices declined even more spectacularly; sending a gigabyte of data is now $1,250,000$ times cheaper than 30 years ago!

Another aspect of this revolution has to do with the R\&D in biotechnology and genetic engineering. The impact of these changes may be particularly great (in a matter of ten or twenty years) in pharmaceutics, making it possible to launch large-scale, and hence relatively cheap production of antidotes to many ailments that

* Grzegorz W. Kolodko is the Director of TIGER (Transformation, Integration and Globalization Economic Research) - economic think-tank, affiliated with the Leon Kozminski Academy of Entrepreneurship and Management, Warsaw, Poland. 
afflict mankind today. However, apart from the richer social strata in the most affluent nations, where the abrupt increase of life expectancy by five or ten years will not cause a public finance crisis, the remaining part of mankind is, regrettably, totally unprepared, in economic terms, to handle such developments.

In many countries this aspect of scientific progress is unlikely to have an initial advantageous effect on the economic situation, because it will impose upon the society a burden of additional expenditure connected with the less favourable dependency ratio, i.e. the ratio of the retired population over the number of employed people, i.e. the active labour force. Unless this is compensated for by increased labour and capital productivity, the growth of per capita output may even slow down - not because more people will be born, but because they will live longer.

But it may also happen - hopefully - that other aspects of the ongoing industrial revolution will give a sufficient stimulus to economic efficiency to ensure that the increased productivity of those in employment will avert the impending crisis (this effect, however, will be likewise largely restricted to the richest societies). If this is the case, the net result of all the changes in the spheres of production and distribution connected with scientific and technological progress will allow the dynamic equilibrium to be preserved at both the economic-cum-financial and socio-political levels. Such a scenario may or may not materialise. At any rate, we are going to face many new theoretical and practical problems, which carry financial, cultural and political implications.

In this perspective, special importance should be attached to the development of the Internet, which is going to expand onto ever-new areas of the economy, as well as the attendant political and cultural issues. The Internet - together with its technological, institutional and cultural environment - is the foundation of the 'new economy' that emerged at the turn of the century. However, actually there is no such thing as the 'new economy'; there are only new technologies of production and distribution, which, to be sure, do have a qualitative influence on ways of doing business.

The announcement of the 'death' of the business cycle as well as the inflation vs. unemployment trade-off turns out - as it did in the case of Mark Twain's death premature. Changes in this field can be explained within the existing paradigm of economics (FRB 1999, Economist 2000, Wojtyna 2001). Thus, in spite of all the new technologies and forms of economic activity, the old laws and regularities described by traditional economics are still alive and well beginning with the eternal law of supply and demand.

One should also bear in mind that the concept of 'new economy' and the (often spuriously) innovative attempts at its theoretical explanation are heavily biased in favour of the American outlook on reality. Most of the new theoretical fads in this field are now experiencing a 'hard landing', together with the entire US economy, 
where GDP growth has slipped several percentage points below the level maintained throughout the 1990s (Donovan 2000, Economist 2001). Even so, many observations and theoretical generalisations made during the boom of the 'new economy' companies, especially in the US, remain valid.

What is more, the failure and demise of many 'dotcom' companies, following the end of that boom, carries new impulses and challenges, both theoretical and practical, for the 'new economy.' Even though Amazon.com lost about 90 per cent of its market value in less than a year, the fact remains that the Internet is changing the world: first in the most developed countries and then, as its scope of coverage increases, also in other areas of the global village, because the Web changes the ways people communicate.

This concerns in the first place the rate of information exchange, which dramatically reduces transaction costs. In 1860 , sending a two-word cable across the Atlantic cost the equivalent of today's $\$ 40$. Nowadays, this amount of money would, theoretically, suffice to transmit the contents of the entire Library of Congress. Since 1930, the cost of a London-New York telephone call has decreased by a factor of 1,500. Since 1970, the real cost of computing power has dropped by 99.999 per cent and the only reason it is valid for the cost calculation is the enormous amount of operations performed.

\section{The Web Economy}

Ever more transactions are moving to the Web, both on the 'business-to-business' (B2B) and 'business-to-consumer' (B2C) platforms. This generates cost savings, while stimulating efficiency-enhancing competition (Shapiro and Varian 1999, OECD 2000a). An increasing number of transactions and transfers will also be effected on the G2B ('government - to - business') and B2G ('business - to government') platforms, as well as the G2Cn ('government-to-citizen') and $\mathrm{Cn} 2 \mathrm{G}$ ('citizen-to-government') platforms, especially in connection with public procurement, tax returns and transfers within the health-service and social-security systems in those cases where these involve state and/or local-government participation.

The expansion of contracts and transactions concluded and executed in virtual space is an irrevocable process, although with regard to its scale, pace as well as dynamics and pattern, there are still more questions than answers. However, if this process is to be significant for the economy as a whole, a certain critical saturation of Internet users must be reached. In the case of electricity, which gave a powerful stimulus to the second industrial revolution (and the impact of the Internet is comparable), clearly noticeable growth acceleration occurred only 40 years after it 
was first applied in the manufacturing process. The Internet develops much faster so we will not have to wait that long. But even in the US, the 'new economy' stemming from the Internet revolution did not gain momentum until nearly half of the households had acquired a computer and access to the Web.

For other countries, such a saturation level is still a long way off, but they are making rapid progress (Eriksson and Adahl 2000). Thus the technologically less advanced economies will also soon feel the effects of the proliferation of the Internet. Although considerable improvements are needed in the sphere of the physical infrastructure necessary for the smooth functioning of the Web, some regions of the technologically less advanced, and sometimes even backward, economies may even now take advantage of the opportunities offered by the computer and Internet revolution.

In West Bengal, for instance, there are merely 27 telephone lines per 1,000 inhabitants; Calcutta, a city of 10 million or so inhabitants, has only 4.5 computers per 1,000 inhabitants (Mulligan 2001). In the Indian countryside, these statistics are even less encouraging. But even in a poor country like India, alongside a great many old problems unsolved thus far, segments of the 'new economy' are already budding. What is more, they are not confined to the best-developed Bangalore region (which matches in some respects Europe and America), but precisely in the poor Calcutta, which, to be sure, was not chosen by Mother Teresa as her working place by accident. In this very city, less than a year after the first free local Internet service was launched, it had as many as 300,000 fairly regular users. Access to the Web has an impact on their activities, skills, and productivity and thus also on the forms of economic activity they are engaged in.

In some regions of the world, the Internet saturation level - and, therefore, also the scope for the emergence and expansion of various forms of economic activity, as well as access to the attendant cultural changes, in particular, the new educational opportunities - is far less satisfactory. It is so despite the relatively higher (in some cases) development level as measured by per capita GDP. This has to do with a number of factors - cultural (including, for instance, the command of English in a given society), political (the scope of genuine civil liberties and the level of state support for the development of the Web) and economic (structure of income distribution and development of telecommunications infrastructure).

Bearing all this in mind, one should evaluate quite differently the state and prospects of the Internet economy in such postsocialist transition economies as Estonia on the one hand, and Azerbaijan ${ }^{1}$ on the other, if in the latter country only one in approximately 50 households has a computer, and most of these households are concentrated in the capital, Baku. In such cases, it indeed makes more sense to talk about the old problems, which are many, rather than about the chances of the development of the 'new economy', which are slim. 
It is estimated that Internet saturation in Poland will reach 20 per cent of households by 2008 . If this projection proves correct, as well it may, than the critical saturation of 40-50 per cent of households with Internet access may be expected between 2012 and 2015. But it might conceivably be attained earlier. ${ }^{2}$ Of course, given the structure of the Polish economy and society, this threshold will be reached much earlier among the urban population than in the rural area, which still accounts for more than a third of the population.

The Internet changes the ways people study and do research, bears upon the workings of the administration, and has an impact on the expanding entertainment industry. The analogy with television is spurious; the Internet should rather be compared to the literacy. A century ago, society could roughly be divided into those who could read and write, and illiterates. Now a similar division is defined by the access to the Internet and the ability - or lack thereof - to use the Web. This is the ground where the struggle for higher productivity, and hence also better living standards, will take place.

The Internet revolution creates an opportunity to accelerate growth in every country, although not all of them will be able to utilise this chance to the same extent, just like the expansion of railways in the $19^{\text {th }}$ century did not bring the same kind of benefits to everybody. What is needed in the first place is appropriate infrastructure and the necessary institutions (OECD 2000b). ${ }^{3}$ Creative use of the Internet in the context of the development strategy requires policy support, because it is not so much a 'new economy' that is emerging as a new, fourth sector. Once upon a time it was farming and the extraction of minerals that decided about international competitiveness and growth rate. Later on this role was taken over by manufacturing and, subsequently, services. By the same token, of critical importance in the $21^{\text {st }}$ century will be the fourth sector - the Web economy and modern digital technologies that cut through all the areas of economic activity. When dealing with so many old problems in the traditional sectors, it is well worth remembering that the future will largely depend on the fourth sector.

Importantly, the Internet revolution and the expansion of computer networks ubiquitous in the most developed countries, but reduced to a marginal position in less developed economies - will have much broader consequences than perceived today. The Internet is resizing the Earth. There was a time when the accessible world - and hence the size of the markets to penetrate - was defined by geographical or political barriers. But today it is no longer possible to shut off the Amazon Basin, Tibet or the Namibian Desert. No place is 'too far away' any more. We used to talk about a 'shrinking world', as the time necessary to travel, dispatch goods, transfer capital or transmit information from place to place decreased. The modern paradox is that the world has 'shrunk' so much that it has once again started to expand, as the Internet boom pushes back the borders of the global village. 
In many types of economic activity, the problem of distance and the cost it used to involve have been eliminated altogether. Cheap Internet access allows enormous amounts of information to be transmitted practically in real time, between any two places, and at a cost that is negligible in any larger-scale transaction. This is also the way to provide certain types of services and sell a wide range of goods - from books and music ${ }^{4}$ to computer software and technology.

This is why the current phase of the scientific and technological revolution, and especially the explosion of Web technologies has not so much shrunk as greatly inflated the world. The Internet has a similar impact on economic development at the current phase of our civilisation as the discovery of America did five hundred years ago. It adds to the 'old world' a whole new economic dimension in which one can read and write, learn and teach, do R\&D, invest and gain profit, manufacture certain goods and provide services, buy and sell, store and consume.

This is a historic change that accounts for the unprecedented significance of the current breakthrough in the permanent globalisation process (Gavyn, Brookes and Williams 2000; Kolodko 2001b). Enormous amounts of inventiveness and enterprise, as well as significant human- and financial-capital resources are moving to virtual space, where they find extremely favourable conditions for expansion. This proves wrong those visionaries and scholars who imagined that the next great expansion after the Age of Exploration would be oriented towards outer space. Sure enough, this vision may yet materialise, but the age we live in now is one of Virtual Expansion. The new space creates tremendous opportunities, but also poses immense challenges. Like before, not everyone will be in a position to take advantage of the new situation. And the actual gains of those involved will also depend on the remaining two factors that set the pace of the current phase of globalisation - changing political relationships and the evolution of economic knowledge and managerial skills (Kolodko 2001a).

Long time ago John Maynard Keynes - not without a certain nostalgia for the 'good old days' - made an interesting observation: 'What an extraordinary episode in the progress of man that age was which came to an end in August 1914!... The inhabitant of London could order by telephone, sipping his morning tea in bed, the various products of the whole earth. '... he could at the same time and by the same means adventure his wealth in the natural resources and new enterprise of any quarter of the world...' (Keynes 1920). These are the words of John Maynard Keynes, written 80 years ago, not of Bill Gates from 80 days ago. Nowadays one could say, in a Keynesian spirit: 'How extraordinary this age is we live in! Sipping his morning tea in bed, the inhabitant of the world shifts his investments from the Shanghai Stock Exchange to Moscow with a click of the mouse; in the afternoon he moves them to Săo Paulo, taking a peek at Bloomberg's in the process, without even bothering to send the butler for a copy of the Financial Times, as everything is available on-line... Meanwhile, he goes through a heap of mail to and from all corners of the world, 
sending the manuscript of his new book on emerging markets in mere seconds to an addressee thousands of miles away. And this is all provided almost free of charge - for less than the cost of a cup of tea...' But it is also true that in the very same way, without getting out of bed, one can also easily lose a fortune - even on long-emerged markets - for instance by moving one's capital from Dow Jones to the "new economy's' stock exchange, i.e. Nasdaq (or the other way round) at an inopportune moment.

The technological revolution is by itself not enough to keep socio-economic progress going in the age of globalisation. It furnishes ways of overcoming physical barriers and, therefore, there are in principle no economically inaccessible areas of the earth. Accordingly, no regions exist any more where, technically speaking, it would not be possible to invest, manufacture, buy or sell. But other obstacles - political and social borders, cultural and mental differences, trade and tariff barriers - do remain in the way. ${ }^{6}$ Overcoming such obstacles calls for an appropriate policy, since just the technological progress is not able to overcome all of them.

Old problems should be dealt with not only by means of new technologies alone, but also with the help of a new policy - modified and adjusted to the requirements of the 'new economy' and the attendant globalisation. Thus the challenge we face is connected not so much with the emergence of 'new economics' (or 'e-conomics') as with the need for a 'new policy.' Such a policy will have to involve novel co-ordination mechanisms, particularly on a global scale, and to create a new international institutional order, because the existing one is by no means adequate to the requirements of modern global economy. There are also some qualitative changes taking place in this field, driven by various factors, including but not limited to technological progress.

Recently, especially over the last quarter of a century, political attitudes towards free trade and unhindered capital movements have been shifting. Previously - in the days of real socialism on the one hand and neo-colonialism on the other - countries that lagged behind denounced transnational corporations as instruments of capitalist exploitation of the Second and Third Worlds by the First. Now, when a single global marketplace is emerging, the same corporations are perceived as the main source of technology and know-how transfer in the areas of management and marketing, and also as a supply of much-needed capital. In the year 2000 alone, international capital transfers related to direct foreign investment approached 1,100 billion dollars.

By its very nature, direct investment is not restricted to the transfer of financial capital, but entails in the first place the movement of capital goods and technologies, and then also of goods manufactured thanks to the new (typically more competitive) productive potential unleashed through the investment. Even so, such huge and rapid capital transfers would not be possible without the increasing reliance of the economy on the Internet. Without the Web, the volume of information transmitted (which is a 
necessary condition of effective and profitable capital transfer, preventing the misallocation of resources) would never have reached its current level. In fact, this is the most significant change brought about by the Internet. Barriers today are not connected any longer with the scope and rate of information transfer, including that pertaining to the manufacturing process and technological know-how, but with the capacity to absorb information and utilise it in reasonable ways.

Such a situation opens up new opportunities for all economies, although capital transfers and direct investments (and hence also the transfers of technology and management skills) turn out to be especially profitable for the best developed countries. It might be seen as a paradox of developmental processes that capital is flowing predominantly to places where it is in abundance anyway, but such is the logic of capital accumulation and allocation. ${ }^{7}$

A new element of this process over the last decade has been the emergence of very large financial flows which accumulate in rich countries as savings, but then are directed - in the form of direct or portfolio investments - to less advanced economies, including postsocialist countries. What made this process at all possible is the transformation. Yet the computerisation and especially the Internet expansion do facilitate it these days too. This might create brighter development prospects for Central and Eastern Europe, as well as for certain emerging markets economies of the former Soviet Union. Such processes do not as yet concern everyone - and, certainly, not to the same extent - but they are gaining momentum.

\section{Catching up}

Against the intricate background of the current phase of globalisation and the scientific and technological revolution (and especially the opportunities created by the 'new economy'), it appears possible to outline some passive scenarios of catching up for transition economies and to formulate certain recommendations concerning an active policy facilitating the realisation of the most favourable scenarios.

The Great Transitional Depression which caused GDP in postsocialist countries to drop in 1990-98, on the average, by as much as cca. 30 per cent is coming to an end (Kolodko 2000b). Gradual transition towards market economy implies that future growth in this part of the world will follow the pattern of contemporary business cycle. In the long run, the variability of growth rate will reflect the ups and downs of such cycle, whose features, however, are not predictable a priori. But in the short-term perspective, we are still waiting for healthy economic growth to spread to the entire postsocialist world. Hopefully, the year 2001 will be a breakthrough in this respect. EBRD projections put GDP growth in Central and Eastern Europe (in terms 
of weighted average) at 4.7 per cent and in the Commonwealth of Independent States at 3.6 per cent (EBRD 2000).

Various output growth projections exist for the years to follow, but no one predicts a further GDP drop in any of the transition economies in a medium-term perspective. Only in a handful of cases is a drop of output expected, and that only for a single year. Therefore, GDP should look far more promising in 2004(5) than it did in 1989 and 1999 , although the scope of that change will not be as great as it might be wished. By 2004 (the former Soviet republics) or 2005 (Central and Eastern Europe), only 11 out of the total of 27 countries (including Yugoslavia and Bosnia-Herzegovina) will exceed the GDP level of 1989. At the opposite extreme there will be 7 countries with GDP still below three quarters of the initial level. And by that time, 15 years ( sic) will have elapsed since the beginning of the transition, that is, if we accept 1989 as the conventional beginning of this process (Table 1).

Table 1.: Growth rate in 2000-4(5) and GDP index (fixed prices) in 2004(5) $(1989=100$ and $2000=100)$

\begin{tabular}{|c|c|c|c|c|c|c|c|c|c|c|c|c|}
\hline & \multirow{3}{*}{$\begin{array}{c}\text { Index } \\
2000 \\
1989= \\
100\end{array}$} & & & & & & & \multicolumn{2}{|c|}{$\begin{array}{c}\text { Index } \\
2004(5)^{\star}\end{array}$} & \multicolumn{3}{|c|}{ Average Ranking } \\
\hline & & \multicolumn{6}{|c|}{ Growth Rate } & \multirow[b]{2}{*}{$\begin{array}{l}2000 \\
=100\end{array}$} & \multirow[b]{2}{*}{$\begin{array}{l}1989 \\
=100\end{array}$} & \multirow[b]{2}{*}{$\begin{array}{c}2001-4 \\
(5)\end{array}$} & \multirow{2}{*}{$\begin{array}{l}\text { Index } \\
2004 \\
(5)\end{array}$} & \multirow[b]{2}{*}{$\begin{array}{l}\text { Average } \\
\text { growth }\end{array}$} \\
\hline & & 2000 & 2001 & 2002 & 2003 & 2004 & 2005 & & & & & \\
\hline Poland & 127.0 & 4.1 & 3.8 & 4.6 & 5.0 & 5.1 & 4.2 & 124.9 & 158.6 & 4.5 & 1 & 17 \\
\hline Albania & 104.2 & 8.0 & 9.1 & 8.8 & 7.8 & 7.3 & 6.9 & 146.8 & 152.9 & 8.2 & 2 & 2 \\
\hline Slovenia & 113.7 & 4.3 & 4.1 & 4.6 & 4.8 & 4.8 & 5.1 & 125.7 & 142.9 & 4.5 & 3 & 18 \\
\hline Slovakia & 103.0 & 2.6 & 4.2 & 5.2 & 5.6 & 6.0 & 5.4 & 129.3 & 133.2 & 4.7 & 4 & 16 \\
\hline Hungary & 104.6 & 5.4 & 5.5 & 5.2 & 4.3 & 4.6 & 4.6 & 126.7 & 132.5 & 5.0 & 5 & 12 \\
\hline $\begin{array}{l}\text { Czech } \\
\text { Republic }\end{array}$ & 95.7 & 2.3 & 4.4 & 5.8 & 5.6 & 4.3 & 4.2 & 126.8 & 121.3 & 4.5 & 6 & 19 \\
\hline Bulgaria & 82.7 & 4.5 & 5.0 & 5.3 & 5.0 & 4.5 & 4.3 & 126.5 & 104.6 & 4.9 & 7 & 13 \\
\hline Uzbekistan & 95.3 & 0.8 & -1.0 & 2.4 & 3.9 & 4.1 & na & 109.6 & 104.5 & 2.4 & 8 & 24 \\
\hline Romania & 77.6 & 2.2 & 6.2 & 5.9 & 6.0 & 5.4 & 5.1 & 132.1 & 102.5 & 5.7 & 9 & 6 \\
\hline Estonia & 80.6 & 6.1 & 6.0 & 5.8 & 5.9 & 5.8 & na & 125.7 & 101.3 & 5.9 & 10 & 4 \\
\hline $\begin{array}{l}\text { FYR } \\
\text { Macedonia }\end{array}$ & 77.9 & 5.5 & 5.4 & 5.6 & 5.3 & 5.2 & 5.4 & 130.0 & 101.2 & 5.4 & 11 & 7 \\
\hline Croatia & 79.9 & 2.7 & 3.3 & 4.5 & 4.4 & 4.1 & 4.0 & 122.0 & 97.5 & 4.1 & 12 & 22 \\
\hline Kazakhstan & 67.6 & 3.3 & 4.6 & 7.6 & 5.7 & 5.5 & na & 125.5 & 84.8 & 5.9 & 13 & 5 \\
\hline Turkmenistan & 66.8 & 4.3 & 4.6 & 4.8 & 5.9 & 6.2 & na & 123.3 & 82.4 & 5.4 & 14 & 8 \\
\hline Belarus & 82.0 & 1.1 & -4.2 & -1.2 & 1.6 & 3.2 & na & 99.2 & 81.4 & -0.2 & 15 & 25 \\
\hline Lithuania & 65.4 & 2.3 & 6.0 & 5.5 & 5.5 & 4.5 & na & 123.3 & 80.6 & 5.4 & 16 & 9 \\
\hline Kyrgyzstan & 65.8 & 7.0 & 4.2 & 5.0 & 5.8 & 5.7 & na & 122.4 & 80.5 & 5.2 & 17 & 11 \\
\hline
\end{tabular}




\begin{tabular}{|l|c|c|c|c|c|c|c|c|c|c|c|c|}
\hline Armenia & $\mathbf{6 1 . 3}$ & -5.4 & 7.7 & 4.1 & 4.6 & 4.7 & na & $\mathbf{1 2 2 . 8}$ & $\mathbf{7 5 . 3}$ & 5.3 & 18 & 10 \\
\hline Latvia & $\mathbf{6 2 . 1}$ & 4.7 & 5.5 & 4.8 & 4.5 & 4.3 & na & $\mathbf{1 2 0 . 5}$ & $\mathbf{7 4 . 8}$ & 4.8 & 19 & 14 \\
\hline Russia & $\mathbf{6 0 . 8}$ & 5.9 & 4.5 & 4.1 & 4.0 & 3.9 & na & $\mathbf{1 1 7 . 5}$ & $\mathbf{7 1 . 5}$ & 4.1 & 20 & 21 \\
\hline Azerbaijan & $\mathbf{5 0 . 3}$ & 7.3 & 8.4 & 8.9 & 8.2 & 7.8 & na & $\mathbf{1 3 7 . 7}$ & $\mathbf{6 9 . 3}$ & 8.3 & 21 & 1 \\
\hline Tajikistan & $\mathbf{4 5 . 7}$ & 4.3 & 6.5 & 6.6 & 6.4 & 6.3 & na & $\mathbf{1 2 8 . 4}$ & $\mathbf{5 8 . 7}$ & 6.5 & 22 & 3 \\
\hline Ukraine & $\mathbf{3 7 . 6}$ & $\mathbf{4 . 2}$ & 3.9 & 4.4 & 4.7 & 4.1 & na & $\mathbf{1 1 8 . 2}$ & $\mathbf{4 4 . 5}$ & 4.3 & 23 & 20 \\
\hline Georgia & $\mathbf{3 3 . 8}$ & -4.3 & 4.6 & 4.8 & 4.7 & 5.0 & na & $\mathbf{1 2 0 . 5}$ & $\mathbf{4 0 . 7}$ & 4.8 & 24 & 15 \\
\hline Moldova & $\mathbf{3 0 . 5}$ & -6.0 & 3.7 & 3.2 & 2.9 & 2.8 & na & $\mathbf{1 1 3 . 2}$ & $\mathbf{3 4 . 5}$ & 3.2 & 25 & 23 \\
\hline $\begin{array}{l}\text { Bosnia- } \\
\text { Herzegovina }\end{array}$ & $n a$ & 9.3 & 8.8 & 8.1 & 7.7 & 6.6 & 5.4 & 147.6 & $n a$ & 8.1 & $x$ & $x$ \\
\hline Yugoslavia & $n a$ & 7.0 & 11.7 & 7.9 & 6.7 & 6.7 & 7.2 & 146.8 & $n a$ & 8.0 & $x$ & $x$ \\
\hline
\end{tabular}

Note: * 2004 for the former USSR; 2005 for Central and Eastern Europe. na - data not available. Source: Indices calculated on the basis of EBRD and PlanEcon. Data for $2000-$ PlanEcon 2000b; for Poland - Central Statistical Office (GUS). Forecast for 2001-05 after PlanEcon 2000a and 2000b; forecast for Poland for 2001-03 after Citibank Poland, for 2004-05 after PlanEcon 2000b (for 2001-03 PlanEcon forecast assumed GDP growth in Poland, respectively, of 5.5; 5.4 and 5.1 percent; see PlanEcon 2000b).

A closer look should be taken at per capita GDP on a purchasing power parity (PPP) basis. This is the right indicator to serve as a starting point for the process of closing the distance between postsocialist economies and higher developed countries (Table 2).

Table 2.: Per capita GDP in 1999 and 2003(4) (in PPP-adjusted US dollars)

\begin{tabular}{|c|c|c|c|c|}
\hline & \multirow[b]{2}{*}{1999} & \multirow[b]{2}{*}{$2003(4)$} & \multicolumn{2}{|c|}{ Increase } \\
\hline & & & $\begin{array}{l}\text { US dollars, } \\
\text { PPP-adjusted }\end{array}$ & Growth, percent \\
\hline Slovenia & 14,267 & 17,344 & 3,077 & 21.6 \\
\hline Estonia & 9,096 & 16,048 & 6,952 & 76.4 \\
\hline Czech Republic & 9,472 & 11,442 & 1,970 & 20.8 \\
\hline Slovakia & 8,395 & 10,954 & 2,559 & 30.5 \\
\hline Hungary & 8,063 & 10,648 & 2,585 & 32.1 \\
\hline Croatia & 8,284 & 9,528 & 1,244 & 15.0 \\
\hline Poland & 7,232 & 9,255 & 2,023 & 28.0 \\
\hline Latvia & 6,341 & 7,877 & 1,536 & 24.2 \\
\hline Belarus & 5,722 & 5,737 & 15 & 0.3 \\
\hline Russia & 4,539 & 5,087 & 548 & 12.1 \\
\hline Bulgaria & 3,758 & 4,796 & 1,038 & 27.6 \\
\hline Lithuania & 3,680 & 4,520 & 840 & 22.8 \\
\hline
\end{tabular}




\begin{tabular}{|l|c|c|c|c|}
\hline Romania & 2,962 & 3,837 & 875 & 29.5 \\
\hline Armenia & 2,842 & 3,662 & 820 & 28.9 \\
\hline Macedonia & 2,897 & 3,423 & 526 & 18.2 \\
\hline Turkmenistan & 2,891 & 3,376 & 485 & 16.8 \\
\hline Kazakhstan & 2,482 & 3,028 & 546 & 22.0 \\
\hline Yugoslavia & 1,828 & 3,027 & 1,199 & 65.6 \\
\hline Uzbekistan & 2,612 & 2,721 & 109 & 4.2 \\
\hline Azerbaijan & 1,970 & 2,689 & 719 & 36.5 \\
\hline Ukraine & 2,348 & 2,641 & 293 & 12.5 \\
\hline Georgia & 1,950 & 2,570 & 620 & 31.8 \\
\hline Kyrgyzstan & 2,211 & 2,472 & 261 & 11.8 \\
\hline Moldova & 1,745 & 2,104 & 359 & 20.6 \\
\hline Albania & 1,474 & 2,025 & 551 & 37.4 \\
\hline Tajikistan & 748 & 848 & 100 & 13.4 \\
\hline
\end{tabular}

* 2003 for the former USSR; 2004 for Central and Eastern Europe Source: PlanEcon 2000a and 2000b

Given such a starting point, the question arises about the situation of these countries within the time span of the next generation or two, that is, in the first half of the $21^{\text {st }}$ century. It appears that, with respect to long-term growth capacity, at least four groups of postsocialist economies will emerge (Kolodko 2000c).

The first group may be called the 'gainers'. It will comprise the economies capable of maintaining for a very long time a growth rate, which is at least twice as high as in developed market economies. Growth rate in the European Union provides a possible reference point in this respect. Although future growth rates in the EU are by no means certain, either, it nevertheless appears reasonable to assume that they will generally stay close to the level attained in 1997-2000, that is, ca. 2.5 per cent (IMF 1999). This means that in order to join the ranks of the 'gainers', an economy should maintain for decades to come an average growth rate of at least 5 per cent (between 4 and 6 per cent).

The 'even-runners' make up the second group of economies, capable of developing at a similar pace as the European Union or even slightly faster. The average growth rate in their case should oscillate around 3 per cent (between 2 and 4 per cent). As a result, these economies will not be catching up with the leaders of the European economy, and if they do, it will be an extremely slow process. In relative terms, the distance between the two groups will be changing at a very sluggish pace, if at all. In absolute terms, however, in view of the initial difference, the distance will be steadily growing. Simultaneously, a gap will widen between the 'even runners' and the 'gainers'. 
The third group comprises the 'laggards' - those economies that are unable to turn the transition to advantage and thus, in the long run, to keep up with the growth rate of the EU economies and the postsocialist 'even-runners'. Their long-term growth rate will not exceed 2 per cent, and may even be lower. Their national income will grow, but for many years its growth will be minimal and barely perceptible.

Finally, there is the fourth group - the 'front-runners'. The economies in this category - if it indeed emerges, thanks to favourable circumstances and competent policy - will maintain an average annual growth rate three times higher than in the present-day European Union. This amounts, on average, to a 7.5 per cent growth annually. At this rate, the 'front-runners' will be catching up with the output levels of the EU countries.

The actual rate of economic growth depends on many factors. On the one hand, an emphasis is placed on the initial development level. Certain theories imply that countries with low output levels at present will stand a better chance to attain high growth dynamics in the future. On the other hand, there is no question that advanced technology and mature institutions - which are a domain of relatively more advanced economies - favour faster output growth.

Are we then to expect faster growth in Slovenia - the richest postsocialist economy - or in Tajikistan, the poorest country in this region of the world? Who is going to develop faster: the Czech Republic or Albania? These are by no means rhetorical questions. A great deal will depend on how well particular countries manage to turn to their advantage the extra opportunities brought by globalisation and the transformation, while mitigating the new risks that undoubtedly emerge in connection with these processes, too.

The net balance of the additional benefits and costs, construed in terms of faster or slower growth rates, will crucially depend on the adopted policy and development strategy. The geopolitical situation may be an advantage or a disadvantage, but the key to success is an appropriate growth policy. One of its elements must undoubtedly be the desire to utilise the extra opportunities offered by the computer-era economy. When devising new strategies to meet the challenges of the $21^{\text {st }}$ century, one should try to use this opportunity to solve at least some of the old problems using the instruments of the 'new economy.' Those postsocialist countries that will manage to attain more in this field - for instance, through greater commitment to invest in the development of Internet infrastructure, foster computer literacy in society and provide financial assistance for the development of networks - will achieve faster growth, because this kind of economic environment will enhance the competitiveness of enterprises.

In the next few years, most economic-growth projections for postsocialist transition economies envisage the highest growth rates in poorly developed economies and in those countries which are rebuilding their potential after local 
conflicts, which brought about a sharp drop in output. Such countries enjoy today considerable financial support, which stems largely from external sources (Table 3 ).

Table 3: Projected average annual GDP growth in 2001-04(5)*

\begin{tabular}{|l|l|}
\hline Front-runners & \\
\hline Azerbaijan & 8.3 \\
\hline Yugoslavia & 8.0 \\
\hline Albania & 8.0 \\
\hline Bosnia-Herzegovina & 7.3 \\
\hline Tajikistan & 6.5 \\
\hline Gainers & \\
\hline Estonia & 5.9 \\
\hline Kazakhstan & 5.9 \\
\hline Romania & 5.7 \\
\hline Macedonia & 5.4 \\
\hline Lithuania & 5.4 \\
\hline Turkmenistan & 5.4 \\
\hline Slovakia & 5.3 \\
\hline Armenia & 5.3 \\
\hline Kyrgyzstan & 5.2 \\
\hline Czech Republic & 4.9 \\
\hline Hungary & 4.8 \\
\hline Bulgaria & 4.8 \\
\hline Latvia & 4.8 \\
\hline Georgia & 4.8 \\
\hline Slovenia & 4.7 \\
\hline Poland & 4.5 \\
\hline Ukraine & 4.3 \\
\hline Russia & 4.1 \\
\hline Croatia & 4.1 \\
\hline Even-runners & 3.2 \\
\hline Moldova & \\
\hline Laggards & 0.2 \\
\hline Uzbekistan & \\
\hline Belarus & \\
\hline
\end{tabular}

2001-04 for the former Soviet Union republics; 2001-05 for Central and Eastern Europe. Source: Estimates of PlanEcon 2000a and 2000b. 
Such projections are based both on the extrapolation of current trends and on certain assumptions concerning structural reforms and changes in the economic policy in coming years. This forecast is far less optimistic than similar ones formulated several years ago. The reasons behind such a change of mood include the meager results of the hitherto transformation and also, less importantly, the negative external shocks which not only affected the real economy, but also had an even more dramatic impact on the ways of thinking about this economy and the related expectations. It may thus turn out that - unlike in the early $1990 \mathrm{~s}$ - we are faced with excessive pessimism.

In the longer-term perspective, growth rates in particular countries will differentiate - not least because of the technological progress resulting from the development of the Internet and information technology in general. Some economies will be unable to avoid the threat of recession in the face of external shocks or failures of their economic policies. But many factors influencing growth rate are totally unpredictable at the moment. Numerous old problems will continue to loom large, but the new growth factors that are only just emerging will begin to operate on a fuller-scale basis.

Quite a lot will also depend on the political decisions that may or may not be taken. These, in turn, will have to do with the institutional aspects of development and the functioning of democracy. To be sure, the latter factor can also be capricious, especially in relatively young democracies (Kolodko 2000a). Whereas for some countries the object of the future development game will be to stay on the development path they have managed to enter, for others the stake will be the transition to a faster development path. And for others still, the objective may be to avoid veering off course and falling behind.

In extreme cases, a postsocialist economy may keep expanding without interruption for half a century, maintaining the position of a 'front-runner.' But it may also remain a 'laggard' for just as long, losing distance to all faster-developing economies. Both these scenarios, however, are hardly plausible: there are not many arguments in support of the claim that any given country will maintain an average annual growth rate of 7.5 per cent for 10,20 or even more years, or, conversely, that it will continue all the time on a miserable 1 per cent of output growth (or no growth at all). Rationally, an economy should be expected to remain among the 'gainers' or 'even-runners', rather than end up in any of the extreme categories. This implies that most postsocialist economies will manage to maintain in the long run an average growth rate, ranging between 3 and 5 per cent. 


\section{Passive Scenarios and Active Strategies}

A distinction should be kept between passive scenarios and active strategies. It is obvious that the development processes will depend in the future, as they do now, on a number of variables that evolve, with varying impetus, in various directions. In the case of some of these, all one can do is try to predict their value with greater or lesser accuracy. However, the attainment of the critical mass in the growth process will depend on the adopted policy and the political ability to follow the lead. Geopolitical situation, cultural heritage, human capital quality and labour skills, population size (and hence also the magnitude of the product and service markets), natural resources and the tourist attractiveness of a country - all these are factors relevant to growth prospects. Some of these are given once and for all; others may change in a long time span, and only under the conditions of economic growth.

But what especially matters is policy. Without an appropriate policy even a relatively better position attributable to other factors will not contribute as much as it should to economic development. Policy quality also codetermines expansion rate in the sectors included in the 'new economy.' And although their thriving is contingent first and foremost on grass-root initiative and genuine entrepreneurship (as well as the strengthening of links with the world economy), industrial and educational policies may also prove quite helpful in this respect.

The combination of three factors: favourable geopolitical situation in Central and Eastern Europe, significant advancement of the institution-building process and relatively greater investment in information technology already stimulates growth in the countries aspiring to membership in the European Union. It should be expected that this group will maintain a position among the 'gainers' over the next 10 or 20 years, although some of them may be demoted to a lower league through policy failures or negative external shocks. However, until they catch up with Western Europe (or at least its southern, relatively less developed part), they should be able to return quickly to the accelerated-growth path even if their growth rate occasionally drops below 5 per cent.

Rapid growth crucially depends on the proper co-ordination of the fiscal and monetary policies, well designed industrial and trade policies and the subordination of structural reforms to the growth policy. This is the environment in which the 'new economy' can be expected to overcome the 'old problems'. Otherwise the Internet will be of little avail, for its benefits hardly matter without a well-developed physical infrastructure or in the face of financial instability.

Internet trade thrives when the goods quickly reach the buyer, that is, metaphorically speaking, when there are no potholes in the roads. In order to thrive, it also requires an efficient electronic banking system to handle the transactions, which 
is impossible without appropriate regulation and supervision in the banking sector or under the conditions of high inflation.

In a mood of realism - without undue fascination with the prospects of the 'new economy', which are neither to be brushed aside, nor overestimated - one can thus formulate various hypothetical scenarios of long-term economic growth. In the future, per capita GDP in particular countries will depend on its level at the point of departure (the year 2000) and the pace of growth in the coming decades.

Assuming that per capita GDP, on a PPP basis, in the most developed industrial economies - that is, in the European Union and the US - is nowadays close to $\$ 30,000$, it makes sense to ask how many times the current per capita GDP should increase in postsocialist countries in order to reach at some future point the current level maintained by the leaders. The answer varies widely: from a twofold growth in the case of the best-developed postsocialist economy, that is, Slovenia, which has reached per capita GDP of nearly $\$ 15,000$ by the end of the century, to a forty-fold growth in the case of the least developed Tajikistan, where per capita GDP does not even amount to $\$ 800$.

But the catching-up process has a much broader dimension than just closing the gap between the national income levels in the most developed and less developed countries. Many postsocialist economies and societies do not lag so far behind the highest-income nations as the GDP statistics might suggest. This indicator reflects just the current flow of output and fails to take account of other aspects of development, relevant to the standard and quality of living. Transition economies, for the most part, do not face the illiteracy problem, and they boast secondary-school enrolment rates corresponding to those of developed industrial countries (UNDP 1999). This has significant implications for the future, as it indicates the high quality of human capital and hence a large growth potential which an appropriate policy should be able to activate in full.

Quantitative growth can be seen as a linear process, which is not the case with socio-economic development. The character of the latter significantly changes in the age of globalisation and information-technology proliferation. Its evolution is also driven by the altering values of civic society. In the long run, the contemporary development model will change and so will the measures of development. They will rely to a far greater extent on the quality of human capital, the state of the environment, access to culture and nature, population density in urban areas and other elements ignored by the GDP index.

If the beginning of the new millennium is to be seen as a point of departure in the catching-up process, all the circumstances outlined above indicate that the endpoint of this process (if it is ever reached) will vary greatly from one postsocialist country to another. One must not forget that the most advanced economies are growing, too. Thus the catching-up process is the pursuit of a moving target. However, even to 
attain, in reasonable time, the current GDP level of the leaders would be quite an achievement. When this is going to happen, if at all, will depend on the development path taken by a given country - whether it is one of the 'front-runners' or merely an 'even-runner.' The 'laggards', of course, will not count (Table 4).

Table 4: The year of catching up with the developed countries, along various development paths (in 1995 dollars, on PPP basis)

\begin{tabular}{|c|c|c|c|c|}
\hline & \multirow{2}{*}{$\begin{array}{l}\text { Per capita GDP in } \\
2000\end{array}$} & \multicolumn{3}{|c|}{ Year of attaining a per capita GDP of $\$ 30,000$} \\
\hline & & Front-runners & Gainers & Even-runners \\
\hline Albania & 1,569 & 2041 & 2060 & 2100 \\
\hline Armenia & 3,009 & 2032 & 2047 & 2078 \\
\hline Azerbaijan & $2,10 \mathrm{I}$ & 2037 & 2055 & 2090 \\
\hline Belarus & 5,238 & 2024 & 2036 & 2059 \\
\hline Bulgaria & 3,930 & 2028 & 2042 & 2069 \\
\hline Croatia & 8,484 & 2017 & 2026 & 2042 \\
\hline Czech Republic & 9,699 & 2016 & 2023 & 2038 \\
\hline Estonia & 9,606 & 2016 & 2023 & 2038 \\
\hline Macedonia & 3,017 & 2032 & 2047 & 2077 \\
\hline Georgia & 2,099 & 2037 & 2055 & 2090 \\
\hline Hungary & 8,525 & 2017 & 2026 & 2042 \\
\hline Kazakhstan & 2,576 & 2034 & 2050 & 2083 \\
\hline Kyrgyzstan & 2,279 & 2036 & 2053 & 2087 \\
\hline Latvia & 6,681 & 2021 & 2031 & 2051 \\
\hline Lithuania & 3,872 & 2028 & 2042 & 2069 \\
\hline Moldova & 1,805 & 2039 & 2058 & 2095 \\
\hline Poland & 7,575 & 2019 & 2028 & 2047 \\
\hline Romania & 3,124 & 2031 & 2046 & 2076 \\
\hline Russia & 4,654 & 2026 & 2038 & 2063 \\
\hline Slovakia & 8,707 & 2017 & 2025 & 2041 \\
\hline Slovenia & 1,802 & 2010 & 2014 & 2024 \\
\hline Tajikistan & 770 & 2051 & 2075 & 2124 \\
\hline Turkmenistan & 3,004 & 2032 & 2047 & 2078 \\
\hline Ukraine & 2,357 & 2035 & 2052 & 2086 \\
\hline Uzbekistan & 2,681 & 2034 & 2048 & 2082 \\
\hline Yugoslavia & 2,108 & 2037 & 2055 & 2090 \\
\hline
\end{tabular}

Future projections: author's calculation (as explained in the text; see Kolodko 2000c for further discussion). 
All the alternative growth paths indicate how great a distance remains to be covered in order to close the development gap that arose over the centuries and, unfortunately, further increased in the past decade, as the postsocialist systemic transformation took an excessively spontaneous turn. It may well be that to close this gap fully will require not half a century, but several of them. Science and technological progress - including everything that is covered by the heading 'new economy' - can certainly contribute towards bridging this gap. Therefore, without placing unreasonable hopes in the potential and prospects of the 'new economy' in postsocialist transition economies, we should nevertheless seek to utilise all the opportunities it presents in order to attain long-term growth as well as sustained and fast socio-economic development.

\section{NOTES}

' In Azerbaijan the GDP per capita (according to purchasing power parity) has been evaluated in 2001 at 2,315 dollars (PlanEcon 2000a), whereas in India - an extremely diversified country - was oscillating within the range from 1,000 to 2,000 dollars.

2 According to the estimation of Bank Handlowy, already in 2010 as many as 17 million people, that is about 42 per cent of society, will have an opportunity to access the Internet at their homes.

${ }^{3}$ The lack of a proper regulation - what is somehow forgotten from time to time by the market fundamentalists - can cause certain pathologies, instead of progress. Long time ago there used to be the accidents in transport, which by all means must be regulated carefully in details, and now there is the crime in the virtual space. If during the previous ten years there were world-wide (yet mainly in the US) approximately 34,000 cases of breaking into somebody else computers systems, in 2000 there were already as much as about 60,000 of such cases. This time, however, all over the world, because nothing is going so fast global as the Web, i.e. the Internet.

${ }^{4}$ What has been experienced by the leader in this field - the Web firm Napster - is quite instructive with this regard. So, first this firm - intermediating in the transfers of music hits, recorded through using the computer in compressed MP3 format - expanded remarkably world-wide. Later however - in the aftermath of the legal proceedings undertaken in favour of the copyrights protection and due to co-ordinated action of recording firms concerned about their own profits - the activities of Napster have become significantly limited and brought under control. Such kind of regulation is happening more and more subsequently toward spontaneously emerging Internet activities. Even if initially such initiatives are not commercially oriented, at the instant there are entering the areas where any businesses are being made, it must lead them too into the profit oriented endeavour. The recent Napster experience is the best case in point here.

${ }^{5}$ Nasdaq - the index of the American 'new economy' firms, resulting from the market valuation of the companies associated mainly with the manufacturing of computer hardware and software, the development of the Internet and the expansion of various forms of e-business - first jumped to over 5,000 points, and then drastically fell below psychological barrier of 2,000 points. Just during 12 subsequent 
months - between mid-March of 2000 and 2001 - it did decrease by 57 per cent, falling from 4,586 to 1,972 points. At the same interval, the stock exchange index of the 'old economy', i.e. Dow Jones, had lost only 1,6 per cent of its value! If the Nasdaq index had peaked during the market euphoria on the wave of fast expansion of the „new economy' firms reaching the maximum level of 5,043 points, in the early phase of „hard landing' of the American economy at the spring of 2001 it has reached the bottom of 1,923 points. As for the Dow Jones index, the weakening of the economic expansion and the change of the investors' market sentiments has lead only to its fall by 14,9 per cent, from the maximum level of 11,720 at the time of exuberant market bubble down to 9,974 points in mid-March of 2001 .

${ }^{6}$ The belief in the progressive force of the Internet revolution will remain just another illusion, as long as there will be cultural backwardness and illiteracy around. First it is necessary to be able to read and write and then to do so in English, and only later one can take full advantage of using the Internet, since as much as about 95 per cent of all information and data on the Web is provided in English. Yet in such populous countries as India, Pakistan, or Egypt over half of women and about 40 per cent of men are illiterate. Thus, to take an additional chance, which is given by globalisation and the 'new economy', more than ever the fundamental progress in education, is needed. It also quite relevant toward the postsocialist countries, where (especially in the former Soviet Union republics) the knowledge of English language - i.e. the lingua franca of the Internet and the contemporary world - is still very meager.

${ }^{7}$ As much as 6,5 per cent ( 57,6 billion dollars) has been absorbed in 2000 by China and additionally 2,3 per cent ( 20,5 billion) by Hong Kong. Hence, China and Hong Kong - attracting together 80,1 billion dollars, i.e. 8,8 per cent of global value of foreign direct investment - has taken the third place world-wide, following the USA (26,6 per cent, or 236,2 billion) and the UK ( 9,3 per cent, or 82,5 billion). Only at the fourth position the 'engine' of the European economy, i.e. Germany, has been placed, in which country the rest of the world has invested directly 68,9 billion dollars, that is 7,8 per cent of total global flow. All East Central European and post-Soviet transition economies have absorbed in 2000 about 27-28 billion dollars, of which to Poland has gone quite a good share of about 9,3 billion. This is just 0.85 per cent of the world value of direct foreign investments, however by the same time it is more than the Polish contribution of 0.6 per cent to the world output.

${ }^{8}$ There are not many examples of such a remarkable growth, however the Chinese economy, which has maintained an average growth of nearly 10 percent annually over the last three decades, has demonstrated that long-term sustainability of this pace under certain circumstances might be feasible.

\section{REFERENCES}

Donovan, P., (2000), 'Challenging America's New Economy Supremacy', UBS Warburg New Economic Perspectives, No. 3.

EBRD, (2000), 'Transition report 2000. Employment, skills and transition', London: European Bank for Reconstruction and Development.

Economist, (2000), 'Untangling e-conomics', The Economist, September $23^{\text {rd }}$. (2001). 'What a peculiar cycle', The Economist, March $8^{\text {th }}$.

Eriksson, J., Adah, M., (2000), 'Is there a 'New Economy' and is it Coming to Europe?', Bank of Sweden Economic Review, No. 1.

FRB, (1999), 'The New Paradigm' (Federal Reserve Bank of Dallas Annual Report), Dallas, Texas. Gavyn, D., Brookes, M., Williams, N., (2000), 'Technology, the Internet and the New Global Economy', Goldman Sachs Global Economics Paper, No. 39. 
Keynes, J. M., (1920), 'The Economic Consequences of the Peace', New York: Harcourt Brace and Howe.

Kolodko, G. W., (2000a), 'From Shock to Therapy. The Political Economy of Postsocialist Transformation', Oxford University Press, Oxford-New York.

(2000b), 'Post-Communist Transition. The Thorny Road', University of Rocheter Press, Rochester, NY and Woodbridge, Suffolk, UK.

(2000c), 'globalisation and Catching-up. From Recession to Growth in Transition Economies', IMF Working Paper, WP/00/100, International Monetary Fund, Washington, DC, (June).

(2001a), 'Moja globalizacja, czyli dookoła świata i z powrotem' [My globalisation, or Around the World and Back Again], TNOiK, Torun.

(2001b), 'Globalisation and Transformation. Illusions and Reality', TIGER Working Paper Series, No. 1 (January).

Mulligan, M., (2001), 'Programming amid poverty', Financial Times, March 7, p. 14.

OECD, (2000a), 'A New Economy? The Changing Role of Innovation and Information Technology in

Growth', Organisation for Economic Cooperation and Developemnt, Paris.

OECD, (2000b), 'A New Economy? The Changing Role of Innovation and Information Technology in Growth', Organisation for Economic Cooperation and Developemnt, Paris.

PlanEcon, (2000a), 'Review and Outlook for the Former Soviet Republics', Washington, D.C.: PlanEcon, Inc., (October).

(2000b), 'Review and Outlook for the Eastern Europe', Washington, D.C.: PlanEcon, Inc., (December).

Shapiro, C., Varian, H., (1999), 'Information Rules: A Startegic Guide to the Network Economy', Harvard Business School Press, Cambridge, Mass.

UNDP, (1999), 'Human Development Report 1997', New York: Oxford University Press.

Wojtyna, A., (2001), 'Does the Traditional Economics Help Us to Understand the 'New Economy'?', paper presented at the International Conference on 'The 'New Economy' and Its Implications for Long-Term Growth in Post-Socialist Countries', TIGER - Transformation, Integration and globalisation Economic Research at Leon Koźmiński Academy of Entrepreneurship and Management (WSPiZ), Warsaw 29-30 March. 